\title{
Mechanotransduction in the muscle spindle
}

\author{
Guy S. Bewick • Robert W. Banks
}

Received: 5 April 2014 /Revised: 9 April 2014 / Accepted: 12 May 2014 / Published online: 3 June 2014

(C) The Author(s) 2014. This article is published with open access at Springerlink.com

\begin{abstract}
The focus of this review is on the principal sensory ending of the mammalian muscle spindle, known as the primary ending. The process of mechanosensory transduction in the primary ending is examined under five headings: (i) action potential responses to defined mechanical stimulirepresenting the ending's input-output properties; (ii) the receptor potential—including the currents giving rise to it; (iii) sensory-terminal deformation-measurable changes in the shape of the primary-ending terminals correlated with intrafusal sarcomere length, and what may cause them; (iv) putative stretch-sensitive channels - pharmacological and immunocytochemical clues to their identity; and (v) synapticlike vesicles - the physiology and pharmacology of an intrinsic glutamatergic system in the primary and other mechanosensory endings, with some thoughts on the possible role of the system. Thus, the review highlights spindle stretchevoked output is the product of multi-ionic receptor currents plus complex and sophisticated regulatory gain controls, both positive and negative in nature, as befits its status as the most complex sensory organ after the special senses.
\end{abstract}

This article is published as part of the Special Issue on Physiological Aspects of Mechano-Sensing.

Electronic supplementary material The online version of this article (doi:10.1007/s00424-014-1536-9) contains supplementary material, which is available to authorized users.

\section{G. S. Bewick $(\bowtie)$}

School of Medical Sciences, Institute of Medical Sciences,

University of Aberdeen, Aberdeen AB25 2ZD, UK

e-mail: g.s.bewick@abdn.ac.uk

R. W. Banks

School of Biological and Biomedical Sciences, University of Durham, Durham DH1 3LE, UK
Keywords Muscle spindle $\cdot$ Mechanotransduction $\cdot$ DEG/ $\mathrm{ENaC} \cdot \mathrm{PLD}-\mathrm{mGluR} \cdot$ Synaptic-like vesicle .

Mechanosensation

\section{Introduction}

In 1926, Adrian and Zotterman [1] published one of the landmark papers in neuroscience. They showed that the response of a single-sensory end-organ to a defined stimulus was transmitted along the afferent nerve fibre in the form of a series of individual action potentials, each of fixed size, whose rate of occurrence varied according to the strength of the input stimulus. They had uncovered a general principal of the organisation of nervous systems - the way in which almost all neurons communicate over long distances, by means of a frequency code of action potentials. The end-organ that was the subject of these studies, and that therefore holds a special place in the history of neuroscience, was the frog muscle spindle, in essence a mechanosensory length transducer. Vertebrate, especially mammalian, muscle spindles are the most complex sensory organ after the special senses of the eye and the ear (for a comparative review of vertebrate muscle receptors, see [12]). A single muscle spindle receives one or more sensory nerve fibres, whose endings are located more or less in the middle of a small bundle of specialised muscle fibres (Fig. 1). These intrafusal fibres also receive their own motor innervation, allowing phasic and tonic aspects of the sensory responses to be independently adjusted (for a review of the structure and function of mammalian muscle spindles, see [9]).

Adrian and Zotterman [1] deliberately chose the muscle spindle to study, at least in part because of the relative simplicity and reliability of its stimulation by defined muscle stretches. In the decades since their fundamental observations, much has been learnt of the way in which the muscle spindle 
Fig. 1 The structure of the primary ending and its enclosing capsules, as illustrated by a representative transverse section (a) cat tenuissimus, 1- $\mu \mathrm{m}$-thick section, toluidine blue stain; $I a-b r$ myelinated banches of the Ia parent axon, ic inner capsule, imf intrafusal muscle fibre, $o c$ outer capsule, $p s$ periaxial space, $s t$ sensory terminal, short arrow myelinated Ia axon, long arrow nuclei of intrafusal nuclear bag fibre; scale bar $=20 \mu \mathrm{m}$.) and by reconstruction $(\mathbf{b}, \mathbf{c})$ from serial transverse sections, including that in (a). b Stereopair of complete ending, with terminals in shades of blue/violet distributed, by repeated branching of the parent Ia afferent nerve fibre (Ia Ia parent axon with myelin in two shades of grey; Schwann cell nuclei in red), to the seven intrafusal muscle fibres present in this case (bif bundle of intrafusal muscle fibres).

The horizontal bar indicates the position of the transverse EM section shown in (a). c Stereopair of one of the first-order branches of the Ia afferent, its two secondorder branches each with a heminode (arrows) and its sensory terminals distributed to one of the intrafusal muscle fibres. Total length of reconstruction $(\mathbf{b}, \mathbf{c})$ is $365 \mu \mathrm{m}$

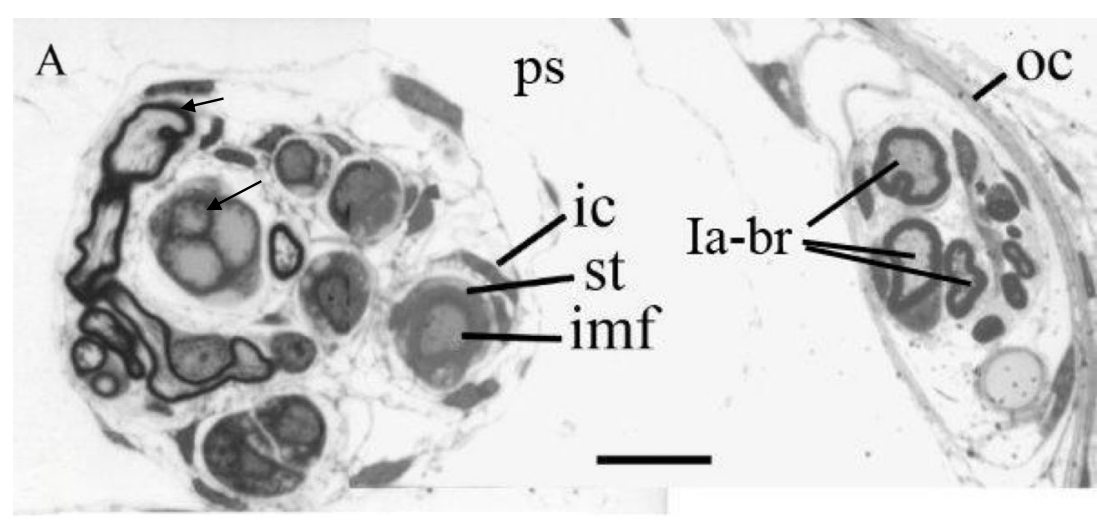

B

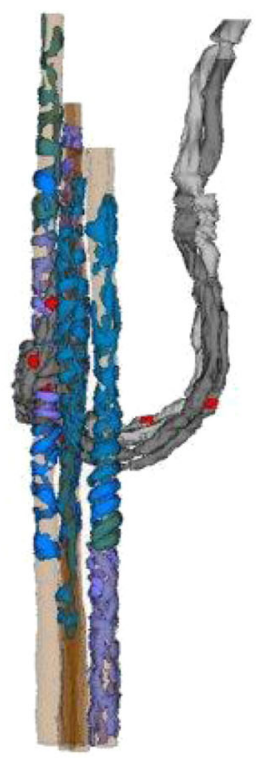

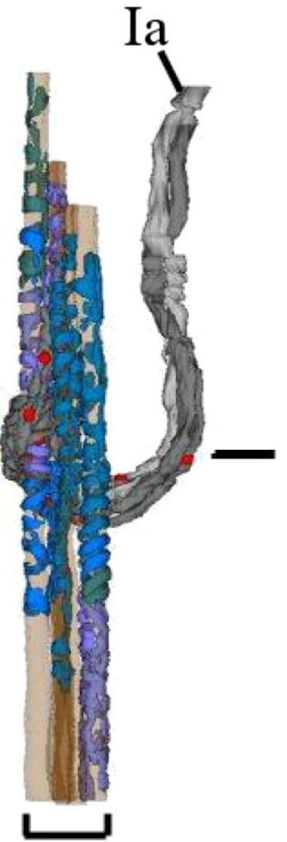

bif
C

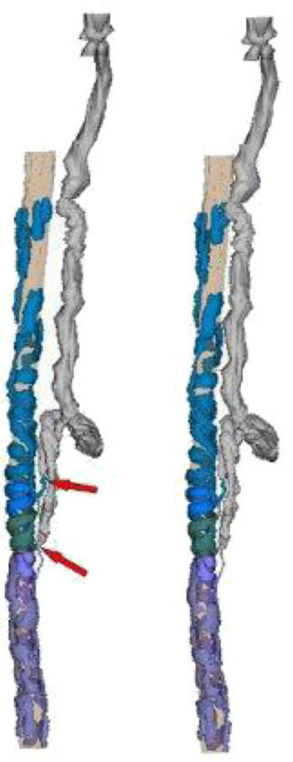

transduces changes in muscle length, brought about by stretching or shortening, though the molecular aspects of the process remain largely unknown despite some tantalising clues (again, see [9] for review). Mechanotransduction, indeed sensory transduction in general, is often treated as a simple feedforward pathway such as: stimulus $\rightarrow$ receptor potential $\rightarrow$ generator potential $\rightarrow$ action potentials. Even phenomena like adaptation can be accounted for by incorporating additional feedforward pathways. However, feedback pathways acting as gain control mechanisms between the input and output of a sensory ending are readily conceivable [47], and one of the main aspects of our recent work concerns the demonstration of the glutamatergic nature, and functional importance, of a system of small $(50 \mathrm{~nm})$ synaptic-like vesicles that may be part of such a mechanism $[10,16]$. The vesicles have long been known to exist in most, perhaps all, mechanosensory endings but have been generally ignored.
Our focus in this review is on the principal sensory ending of the mammalian muscle spindle, known as the primary ending. We shall examine the process of mechanosensory transduction in the primary ending under five headings: (i) action-potential responses to defined mechanical stimuli-representing the ending's input-output properties; (ii) the receptor potential-including the currents giving rise to it; (iii) sensory-terminal deformation-measurable changes in the shape of the primaryending terminals correlated with intrafusal sarcomere length, and what may cause them; (iv) putative stretchsensitive channels-pharmacological and immunocytochemical clues to their identity; and (v) synaptic-like vesicles - the physiology and pharmacology of an intrinsic glutamatergic system in the primary and other mechanosensory endings, with some thoughts on the possible role of the system. 


\section{Action-potential responses to defined mechanical stimuli}

This is not the place to present a comprehensive account of the responses of muscle-spindle primary endings, which would require a detailed consideration of the actions of the intrafusal motor supply as well as a wide range of mechanical stimuli defined in the time [39] or frequency domain [61]. Rather, we give just a few examples of primary endings responding to two of the most widely used patterns of stretch, trapezoidal and sinusoidal, in order to illustrate some key features of the overall transduction process (see Fig. 2). Although the responses shown here were all obtained in the absence of any concomitant motor stimulation, they are abstracted from the first few seconds of protocols that each took $40 \mathrm{~s}$ to complete involving much more complex patterns of combined motor and stretch stimulation [39].

We begin by noting that the responses of a single primary ending to separate presentations of the same stimulus are highly reproducible (Fig. 2a, b), provided any long-lasting mechanical after-effects arising from intrafusal motor stimulation are removed by a conditioning prestretch [11, 53]. The primary-ending response is usually considered in terms of dynamic (or phasic) and static (or tonic) components according to whether the mechanical stimulus is changing with time or not. Thus the ending is much more sensitive (here measured in impulses $\mathrm{s}^{-1} \mathrm{~mm}^{-1}$ ) to increasing length than to instantaneous length; moreover, during a decreasing length change the ending's dynamic sensitivity must be accounted negative, allowing the output to fall to zero in some cases (Fig. 2a). Prominent features of the primary ending's response to periodic sinusoidal stretch include phase advance and distortion (Fig. 2b), both of which may be considered to arise from the nonlinear combination of the effects of separate dynamic and static components [11].

The reproducibility not just of the pattern but of the actual firing rates of the responses of a single primary ending to separate presentations of the same stimulus may be thought remarkable enough, but when different endings, whether from separate spindles in the same muscle or from different preparations, are presented with the same stimulus the close similarity of their responses is surely even more remarkable (Fig. 2c, d). The implicit question: 'How is the activity of the primary ending regulated so as to produce an appropriate output for a given input?' is one to which we shall return in the sections on putative channels and synaptic-like vesicles.

\section{The receptor potential}

Direct recording of the receptor potential in the primary ending's terminals has yet to be achieved, due mainly, perhaps, to their inaccessibility within an inner capsule (Figs. 1a and $4 a, b)$. Equally inaccessible are the heminodes, where preterminal branches of the afferent fibre lose their myelin and where action potentials are thought to be generated (Fig. 1b, c (arrows)) [66]. Banks et al. [11] found between three and nine heminodes in each primary ending of cat tenuissimus spindles; in the more highly branched endings some of the heminodes are sufficiently distant from each other as to be effectively isolated electrotonically, allowing action potentials generated by the heminode with momentarily the highest firing rate to reset other heminodes by antidromic invasion. By eliminating action-potential firing using tetrodotoxin (TTX), and therefore allowing summation of all the receptor currents originating in the separate sensory terminals, Hunt et al. [40] succeeded in recording a continuous, stretchdependent potential from the afferent fibre close to its exit from the spindle (Fig. 3). Depolarising receptor currents were due very largely to an influx of $\mathrm{Na}^{+}$, presumably through stretch-activated channels in the sensory-terminal membrane, but replacement of external $\mathrm{Na}^{+}$with an impermeant cation also revealed a small, stretch-dependent, inward $\mathrm{Ca}^{2+}$ current. Repolarising currents probably due to $\mathrm{K}^{+}$efflux were evident as receptor-potential undershoots beginning immediately after the end of a ramp stretch (postdynamic minimum (pdm)) and at the start of release of static stretch (postrelease minimum (prm)). The postdynamic undershoot appeared to be caused by voltage-gated $\mathrm{K}^{+}$channels, as it could be blocked by tetraethylammonium (TEA), but the release undershoot was more complex and only a late hyperpolarisation was blocked by TEA [40]. The TEA-resistant release undershoot was not affected by removal of external $\mathrm{Ca}^{2+}$, or by changes in $\left[\mathrm{Ca}^{2+}\right]_{\mathrm{o}}$, so Hunt et al. [40] concluded that it was not caused by activation of $\mathrm{K}[\mathrm{Ca}]$ channels.

In 1980, Hunt and Wilkinson [41] extended their study of mechanotransduction in the TTX-poisoned isolated muscle spindle by recording both indirect receptor potential (i.e. propagated to the axon by electrotonic spread) and tension in response to sinusoidal stretch varying in both displacement and frequency. Their results were broadly in line with those obtained some time earlier by Matthews and Stein [51] who had recorded action potentials from in situ spindles, but in addition they [41] were able to show that many of the nonlinearities such as gain compression originally described in the in situ preparation are present in both the receptor-potential and tension responses. The parallelism between the receptor potential and intrafusal tension suggests that many features of the sensory response have their source in the mechanical transmission of the stretch stimulus to the sensory terminals; however, Kruse and Poppele [47] provided compelling evidence that within the linear displacement range the midfrequency dynamics $(0.4-4 \mathrm{~Hz})$ did not arise from the mechanical properties of the contractile apparatus of the intrafusal muscle fibres, but rather were intrinsic properties of the sensory terminals. They explicitly identified $\mathrm{K}[\mathrm{Ca}$ ] channels as in part responsible for the mid-frequency dynamics by providing a negative feedback 

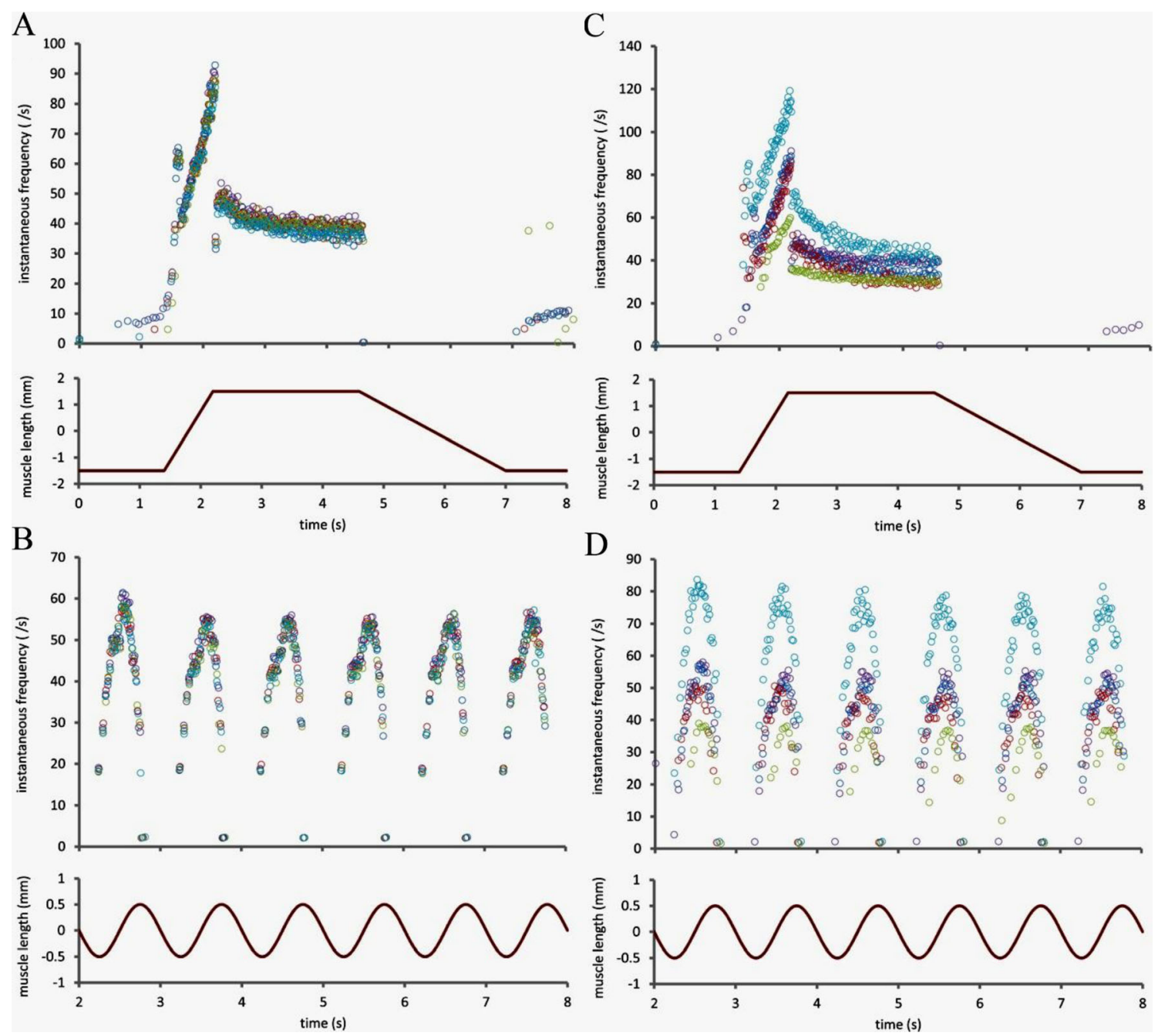

Fig. 2 Examples of muscle-spindle primary endings responding to trapezoidal $(\mathbf{a}, \mathbf{c})$ and sinusoidal $(\mathbf{b}, \mathbf{d})$ stretches applied to the tendon of the muscle (peroneus tertius of cat). $\mathbf{a}, \mathbf{b}$ The reproducibility of the responses when five separate presentations of the stimuli are given to the same primary ending. The responses are superimposed and each response is indicated by different coloured symbols. $\mathbf{c}, \mathbf{d}$ The similarity of responses from five primary endings in four different preparations. The data used to

loop within the overall mechanotransduction process and in support of this, we have recently found immunoreactivity for SK2-type $\mathrm{K}[\mathrm{Ca}]$ channels in the sensory terminals of muscle spindles and lanceolate endings of hair follicles (Shenton et al., unpublished data).

\section{Sensory-terminal deformation}

Direct observation of isolated or semi-isolated muscle spindles shows that stretch of the spindle is accompanied by extension of the sensory region and measurable increase in the spacing between the turns of the primary-ending terminals $[17,62]$. The sensory terminals appear to adhere to the surface of the intrafusal muscle fibres and they do not directly contact

construct the figure were obtained by the method given in [39] and are taken from their unpublished results. The responses are presented as plots of instantaneous frequency in which each symbol corresponds to a single action potential and is positioned according to the time the action potential was recorded (abscissa) and the reciprocal of the time since the previous action potential (ordinate)

any other cellular structure. Intrafusal muscle fibres, in common with skeletal muscle fibres generally, possess an extracellular, collagenous basal lamina, which is in close contact with the plasmalemma of the muscle fibre everywhere except at the sensory terminals (Fig. 4a). Attachment of the basal lamina to the plasmalemma probably involves the dystrophin complex, and dystrophin is missing precisely where the sensory terminals intervene between the basal lamina and muscle fibre plasmalemma [54]. The basal lamina may therefore be an important structural component, helping to locate and attach the sensory terminals to the intrafusal muscle fibres. Stretch of the sensory region is accompanied by deformation of the terminals, first described in frog spindles [14]. In mammalian spindles, the profiles of sensory terminals, when cut in longitudinal section through the sensory region, present a 


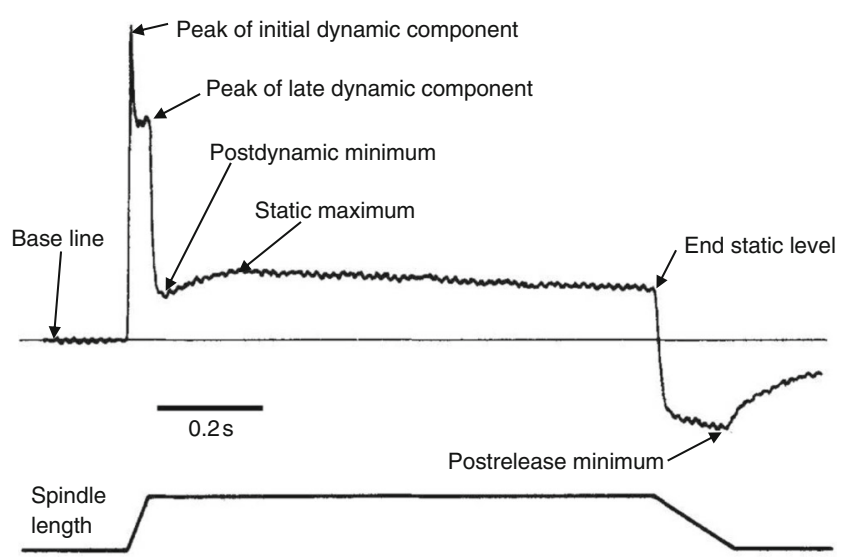

Fig. 3 The receptor potential of a spindle primary ending (top trace) recorded from the Ia afferent fibre in a TTX-poisoned muscle spindle, relative depolarisation upwards, in response to a trapezoidal stretch (lower trace; duration of trace, $1.5 \mathrm{~s}$ ). The various phases of the response are described according to Hunt et al. [40], who identified the pdm and the later part of the prm as due to voltage-dependent $\mathrm{K}$ channels [40]

characteristic lentiform shape that varies in relation to intrafusal-fibre type and amount of static tension (as indicated by sarcomere length, Fig. 4b, c). Analysis of the profile shapes shows that the terminals are compressed between the plasmalemmal surface of the intrafusal muscle fibres and the overlying basal lamina [8]. Assuming that the terminals are constant volume elements, this compression leads to deformation of the terminals from a condition of minimum energy (circular profile) and therefore to an increase in terminal surface area. The tensile energy transfer from the stretch of the sensory region to the terminal surface area may be proposed to gate the presumed stretch-activated channels in the terminal membrane. Well-fixed material shows a fine, regular corrugation of the lipid bilayer of the sensory terminal membrane (Fig. 4a), so it seems likely that the tensile-bearing element consists in cytoskeletal, rather than lipid bilayer, components of the membrane [8].

\section{Putative stretch-sensitive channels}

The stretch-sensitive channel(s) responsible for transducing mechanical stimuli in spindle afferents, as in most mammalian mechanosensory endings, awaits definitive identification. Candidate mechanotrasnducer channels have been reviewed in detail recently [22]. In spindle primary terminals at least, multiple ion channel types must be responsible for generating and regulating the frequency of afferent action potentials. Hunt et al. [40] showed that in mammals while $\mathrm{Na}^{+}$is responsible for $\sim 80 \%$ of the generated receptor potential, there is also a clear involvement of a stretch-activated $\mathrm{Ca}^{2+}$ current. Conversely, the postdynamic undershoot is driven by $\mathrm{K}^{+}$, particularly a voltage-gated $\mathrm{K}^{+}$current. Finally, other studies
$[47,70,79]$ indicate a role for $\mathrm{K}[\mathrm{Ca}]$ currents. Most, perhaps each, of these must involve opening specific channels.

We will first examine the evidence surrounding the putative mechansensory channel(s) carrying $\mathrm{Na}^{+}$and $\mathrm{Ca}^{2+}$ currents. It seems unlikely the whole receptor current is supported by a single type of nonselective cation channel, as $\mathrm{Ca}^{2+}$ is unable to substitute for $\mathrm{Na}^{+}$in the receptor potential [40]. Members of three major channel families have been proposed as the mechanosensory channel; degenerin/epithelial $\mathrm{Na}$ channels (DEG/ENaC), transient receptor potential (TRP) superfamilies [56, 74] and piezos [20]. There is strong evidence for TRP channels as neural mechanosensors in invertebrates, particularly Drosophila [33, 56, 74]. However, there is little evidence for a role in low-threshold sensation in spindles. Strong evidence against them being the major driver of spindle receptor potential is they either display high $\mathrm{Ca}^{2+}$ selectivity or pass $\mathrm{Na}^{+}$and $\mathrm{Ca}^{2+}$ equally well. While piezos 1 and 2 certainly contribute to mechanical responses to nociceptive touch in mammalian sensory neurones, they are nonselective cation channels and there is again no strong evidence for their presence in spindles [20]. Finally, however, there is mounting evidence in mammalian primary afferent neurones, and in the sensory endings of spindles in particular, for the involvement of members of the DEG/ENaC superfamily as mechanosensory channel(s) [4, 44, 67, 68, 71]. Importantly, many channels in this family are highly selective for $\mathrm{Na}^{+}$over $\mathrm{Ca}^{2+}$ and $\mathrm{K}^{+}$[32]. However, their role as stretch-activated channels is disputed [67]. Attempts to show mechanical activation in heterologous systems have been unsuccessful [7, 67], but this may reflect a block by intracellular ATP [49]. We have produced evidence for all four subunits of the $\mathrm{ENaC}$ channel $(\alpha, \beta, \gamma$ and $\delta)$ in spindle primary-sensory terminals, by pharmacology, immunofluorescence and Western blotting (Fig. 5) [71]. $\mathrm{ENaC}$ channels are thought to be heterotrimers [45], of either $\alpha, \beta$ and $\gamma$ or $\delta, \beta$ and $\gamma$ composition, with the $\alpha$ or $\delta$ subunits forming the pore. Another superfamily member are the acid sensitive ion channels (ASICs), where ASIC $1 \mathrm{a} / \mathrm{b}, 2 \mathrm{a} / \mathrm{b}, 3$ or 4 make up the pore, probably in homo/heterotrimeric combination with each other or even $\mathrm{ENaC} \beta$ and $\gamma$ [45]. Their role in wider sensory perception has been extensively reviewed elsewhere [48]. Spindle sensory terminals were indeed immunofluorescent for ASIC2a. All $\mathrm{ENaC} / \mathrm{ASIC}$ labelling in spindle mechanosensory terminals strongly colocalised with synaptophysin, a marker for the synaptic-like vesicles (SLVs) regulating afferent excitability (see next section). Thus, the channels may be stored in intracellular vesicular compartments and delivered to the terminal membrane by vesicle fusion. This would be consistent with inhibition by syntaxin $1 \mathrm{~A}$ of $\mathrm{ENaC}$ currents when these proteins are co-expressed in Xenopus oocytes [64] and with vesicle-associated localisation of immunogold $\mathrm{ENaC}$ labelling in rat kidney epithelium, where $\mathrm{ENaCs}$ regulate $\mathrm{Na}$ fluxes [36]. 


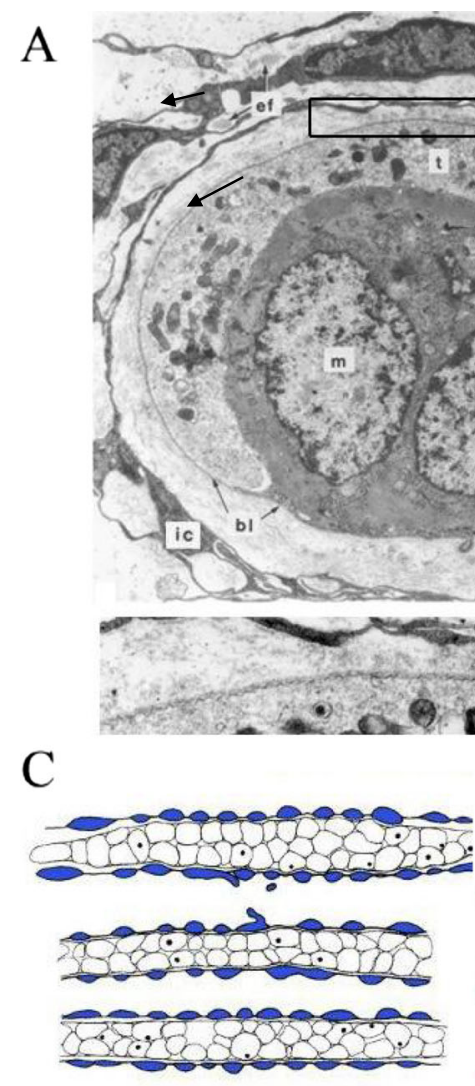

Fig. 4 The fine structure of the sensory terminals of a spindle primary ending $(\mathbf{a}, \mathbf{b})$ and their deformation in response to maintained stretch $(\mathbf{c})$. a Transverse section through an intrafusal muscle fibre ( $m$ label is located in one of the fibre's myonuclei) with an enclosing sensory terminal $(t)$. Note: (i) the basal lamina $(b l)$ of the muscle fibre that is continuous over the outer surface of the sensory terminal and (ii) cells of the inner capsule (ic). Part of the sensory terminal (black rectangle) is enlarged below the main image to show the corrugated nature of its plasmalemma $(t)$ compared with the smooth membranes of the adjacent ic cells. ef elastic fibres. b Longitudinal section through an intrafusal muscle fibre ( $m$ again label is located in the fibre's myonuclei), showing the lentiform profiles of the sensory terminals $(t)$ in this plane. npa nonmyelinated preterminal axon,

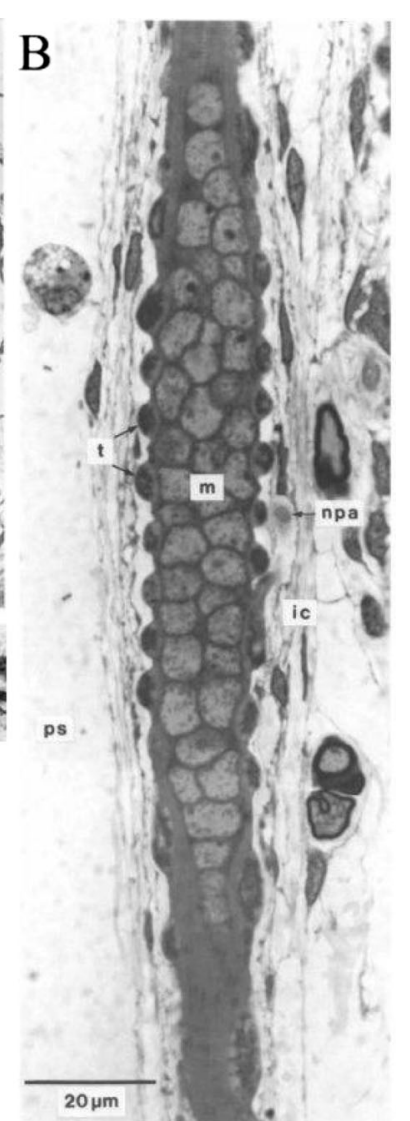

ps periaxial space. c Outline tracing of the section shown in (b), together with similar sections through the same type of intrafusal fibre from two other spindles. Mean lengths of 50 sarcomeres on either side of the primary ending indicate that the spindles were fixed at increasing amounts of maintained tension from top to bottom (2.20-, 2.50- and $2.55-\mu \mathrm{m}$ sarcomere lengths, respectively). Corresponding deformation of the terminal profiles was clearest in the increasing mean radii of the terminal/muscle fibre interfaces $(5.2,20.1$ and $31.9 \mu \mathrm{m}$, respectively). Examples of representative terminal profiles are shown enlarged on the right, with the increased flattening of the terminal/muscle fibre interface on each fibre indicated by an arrow [8]

All ENaCs/ASICs are inhibited by amiloride, and we found spindle stretch-evoked outputs are highly amiloride sensitive. However, there was little discrimination between amiloride analogues, with the exception of hexamethyleneamiloride, which had a particularly steep dose/response relationship (Fig. 5b, c). More recently, we have explored the potential of other $\mathrm{ENaCs}$ as mechanotransducers. When expression was linked to green fluorescent protein, ASIC3-associated fluorescence was found in spindle primary sensory terminals. Our functional studies used a novel assay of stretch-evoked responses in neurites from ASIC3 expressing large-diameter dorsal root ganglion neurones (DRGs). Deformation of the flexible substrate underlying the neurites, to simulate lowthreshold activation, reliably evoked action potentials in an amiloride-sensitive manner. Moreover, DRG-specific ASIC3 deletion ablated this substrate indentation-evoked response.
Interestingly, neither amiloride nor gene deletion affected responses to direct contact-stimulated responses, perhaps analogous to nociceptive stimulation. Finally, DRG-targeted ASIC3 knock out produced significant deficits in fine proprioceptive tasks in vivo, analogous to the light-touch deficits in ASIC2a knockouts [63]. Overall, these findings implicate low affinity $\mathrm{ENaCs}$ as a major component of the spindle mechanotransducer. The presence of multiple channel isoforms, together with the absence of dramatic effects following knock out of single genes, suggests that either yet another whole class of channels remains to be discovered, or there is great functional redundancy in the channels expressed or, perhaps most likely, the primary mechanotransducer channels are composed of heteromultimers from various member of the $\mathrm{ENaC}$ superfamily, analogous to the MEC channels in Caenorhabditis elegans [5]. 
Fig. 5 Evidence for amiloridesensitive $\mathrm{ENaC}$ family members in spindle sensory terminals. a Confocal immunofluorescence images of labelling for $\alpha, \beta, \gamma$ and $\delta \mathrm{ENaC}$ (red) localises to the sensory terminals, doublelabelled with synaptophysin (green). Synaptophysin labels the synaptic-like vesicles in the primary sensory terminals. b Stretch-evoked firing is inhibited by amiloride in a dose-dependent manner, in the range of $1-$ $1,000 \mu \mathrm{M}$. c Similar effects are seen with other amiloride analogues, except hexamethyleneamiloride (HMA) [71]

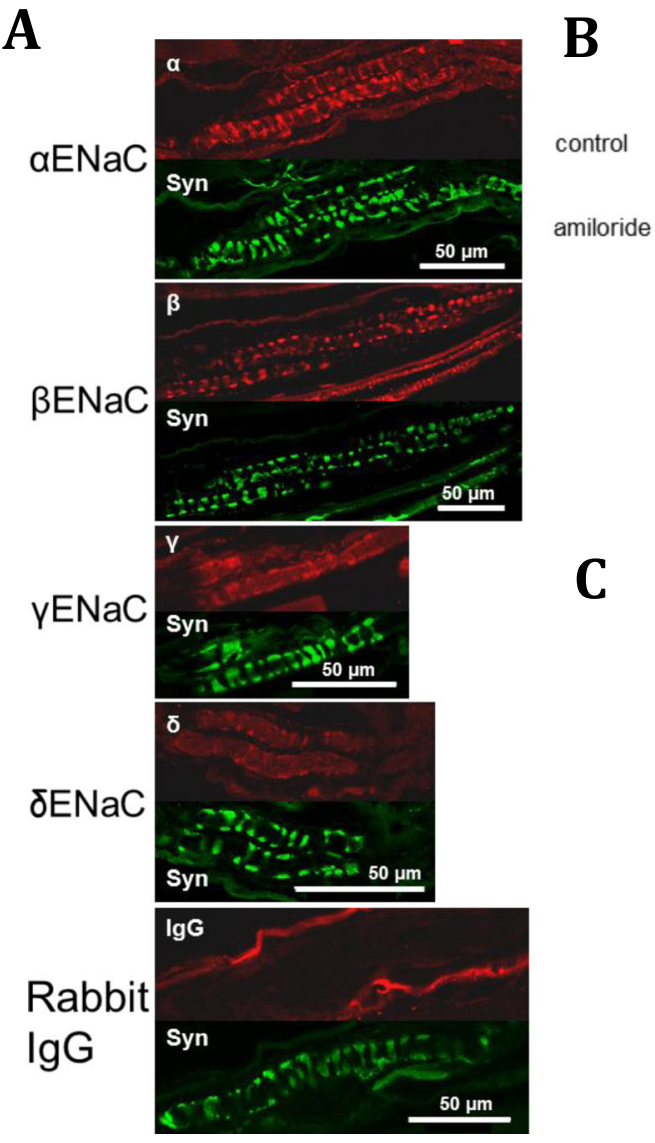

B
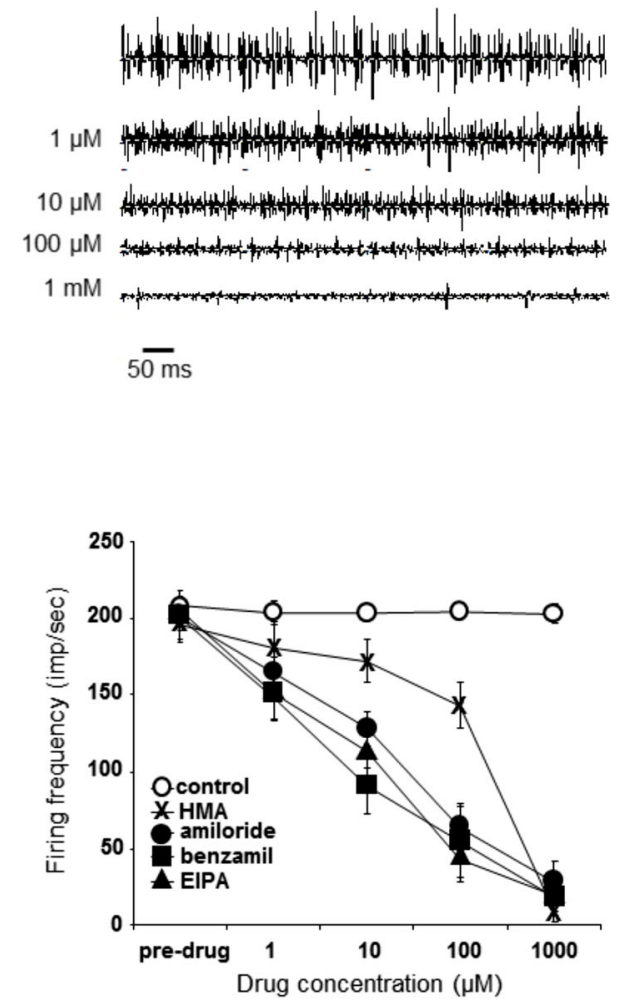

The next question is which channel(s) support the $\mathrm{Ca}^{2+}$ current. While $\mathrm{Ca}^{2+}$ only contributes $\sim 20 \%$ of the receptor current, it is clearly functionally essential. Removal of extracellular $\mathrm{Ca}^{2+}$ or application of the inorganic voltage-gated channel blocker $\mathrm{Co}^{2+}$ rapidly block stretch-evoked firing [16, 47]. We have found similar effects with $\mathrm{Ni}^{2+} / \mathrm{Cd}^{2+}$. As $\mathrm{ENaC}$ $(\alpha, \beta$ and $\gamma)$ channels have a very high $\mathrm{Na}^{+}$selectivity, passing almost no $\mathrm{Ca}^{2+}$, another channel must be responsible for the substantive $\mathrm{Ca}^{2+}$ component to the receptor potential [40]. Several candidates have been suggested, including ASICs, TRPs and even voltage-gated $\mathrm{Ca}^{2+}$ channels. The $\mathrm{Ca}^{2+}$ selectivity or cation nonselectivity of TRP channels makes them candidates, but there has been no systematic study of TRP channels in spindles. If present, it is unlikely to be TRPV1 and TRPM8, as we find the TRPV1 antagonist capsazepine [13] actually enhances stretch-evoked firing in spindles. Conversely, icilin, a particularly potent TRPM8 agonist [13, 77], increases firing only modestly [71]. Other candidate TRP channels include members of the TRPC family, where a number of reports suggest they are associated with mechanotransduction in other cell types, e.g. [30, 35, 69, 72, 73]. However, expression in heterologous systems does not support a role for them directly in mechanotransduction [35] but rather in $\mathrm{Ca}^{2+}$ release from intracellular compartments [33]. Of the ASICs, only ASICla is known to be significantly permeable to $\mathrm{Ca}^{2+}$, and its presence in spindle endings has not been reported. Thus, while a $\mathrm{Ca}^{2+}$-permeable, stretch-activated channel is clearly present, its identity is unclear.

There is, however, significant evidence of important functional roles for voltage-gated $\mathrm{Ca}^{2+}$ and $\mathrm{K}[\mathrm{Ca}]$ channels in modulating stretch-evoked spindle output [47]. L-type voltage-activated $\mathrm{Ca}^{2+}$ channels may indeed contribute to the receptor potential and/or the encoding process, as high nifedipine concentrations inhibit firing [29]. N-type channels have been reported to exhibit mechanical sensitivity in heterologous systems [18]; however, we found the N-type channel toxin $\omega$-conotoxin GVIA had no effect on firing [70].

Interestingly, antagonists of the remaining $\mathrm{Ca}^{2+}$ channels tested, and the $\mathrm{K}[\mathrm{Ca}]$ channels, all increase firing. Thus, $\mathrm{Zn}^{2+}$ (T-type channel blocker) [47] and $\omega$-agatoxin IVA (P/Q-type) [70] both enhanced spindle firing. In fact, $\mathrm{P} / \mathrm{Q}$ channel blockade increased firing rates quite profoundly, to some $300 \%$ of basal rates. This indicates that rather than contribute to the receptor potential, particularly $\mathrm{P} / \mathrm{Q}$-type and perhaps T-type channels help regulate firing rates. Incidentally, $\mathrm{Zn}^{2+}$ is also an activator of $\mathrm{ENaC}$ and piezo channels [34]. Thus, the increased firing may be the first evidence for piezo in spindle sensory terminals.

It seems the $\mathrm{Ca}^{2+}$-channel mediated regulation of firing rates is linked to activation of $\mathrm{K}[\mathrm{Ca}]$ channels. $\mathrm{K}^{+}$outflow 
by $\mathrm{Ca}^{2+}$-dependent opening of these channels will produce hyperpolarisation, tending to dampen firing rates below that expected directly from the depolarising receptor potential. Blocking the channels with apamin (SK), iberiotoxin, charybdotoxin, paxilline (BK) and TRAM 34 (IK), all increase firing $[47,70]$. Conversely, activating the BK channel with NS1419, blocks spindle firing entirely. A complete description of this study is in preparation.

In summary, the mechanosensory channels producing the spindle receptor potential still await definitive identification. The major $(\sim 80 \%)$ current from the mechanosensory channels is due to $\mathrm{Na}^{+}$. There is a minor $(\sim 20 \%)$ contribution from $\mathrm{Ca}^{2+}$, also in a mechanically sensitive manner. Prime candidates responsible for the $\mathrm{Na}^{+}$current are ENaCs and/or ASICs. The $\mathrm{Ca}^{2+}$ component seems likely to flow through ASICla and/or L-type voltage-gated channels, although it may also involve TRP channels. Our results with SK2 suggest a direct contribution of this channel to the receptor potential (Shenton et al., unpublished data), but the remaining $\mathrm{Ca}^{2+}$ and $\mathrm{K}[\mathrm{Ca}]$ channels seem rather to be concerned with regulating the firing frequency in response to the receptor potential through T- and particularly P/Q-type channels, linked to a family of $\mathrm{K}[\mathrm{Ca}]$ channels. While there is evidence for SK, IK and BK, the BK channels certainly play a major role, as their direct activation alone can entirely abolish spindle output. This relationship between P/Q-type and BK channels is reminiscent of the regulation of firing in a number of places in the nervous system. Simultaneous expression of voltage-gated $\mathrm{Ca}^{2+}$ and $\mathrm{K}[\mathrm{Ca}]$ channels to regulate neuronal excitability is common in the CNS $[15,27,50,80]$ and has also been found to control firing in a range of other peripheral mechanosensitive cell types [38,60].

\section{Synaptic-like vesicles}

Populations of vesicles are a prominent feature of muscle spindle primary afferent terminals at the EM level (Fig. 6a, b), as they are in all mechanosensory endings [3, $19,83]$. While these vesicles can vary in size and morphology, most are described as small and clear. When carefully quantified in spindles, the most abundant vesicle population is one of $50 \mathrm{~nm}$ diameter (Fig. 6c). Since the discovery of these vesicles in sensory endings, contemporaneous with their synaptic counterparts [19, 46], sporadic reports show spindle terminals also express functionally important presynaptic proteins: the vesicle clustering protein synapsin I and the ubiquitous synaptic vesicle protein synaptophysin [21] (Figs. 5a and 6d); the vesicle docking SNARE complex protein, syntaxin $1 \mathrm{~B}$ [2]; as well as many presynaptic $\mathrm{Ca}^{2+}$-binding proteins (calbindin-D28k, calretinin, neurocalcin, NAP-22 and frequenin) $[25,26,28,37,42,43,78]$. Several functional similarities have emerged too, including evidence of endocytosis (Fig. 6e, f), and their depletion by black widow spider venom [64]. Despite these commonalities, the role of the vesicles was largely ignored for over 40 years, presumably due to lack of an obvious function in sensory terminals.

Through uptake and release of the fluorescent dye FM1-43, we showed the vesicles undergo constitutive turnover at rest, and that turnover increases with mechanical activity (Fig. 7a, b) [16]. Unlike the stereocilia of cochlear hair cells [31], or many DRG neurones in culture [24], this labelling does not seem to greatly involve dye penetration of mechanosensory channels, as it is reversible, resistant to high $\mathrm{Ca}^{2+}$ solutions, and dye has little effect on stretch-evoked firing in spindles $[16,75]$ or indeed in other fully differentiated mechanosensory terminals [10]. Dye turnover is, however, $\mathrm{Ca}^{2+}$ dependent, as both uptake and release are inhibited by low $\mathrm{Ca}^{2+}$ and the $\mathrm{Ca}^{2+}$-channel blocker, $\mathrm{Co}^{2+}$ (Fig. 7c, d). Thus, vesicle recycling in mechanosensory terminals, as with synaptic vesicles, is $\mathrm{Ca}^{2+}$ dependent, constitutive at rest ( $c f$ spontaneous synaptic vesicle release at synapses) and is increased by activity (mechanical/electrical activity, respectively). However, these terminals are not synaptic, as vesicle clusters (Fig. 6b) and recycling (Fig. 6e, f) are not specifically focussed towards the underlying intrafusal fibres nor, apparently, around specialised release sites (RWB, unpublished data). While trophic factors are undoubtedly secreted from primary terminals to influence intrafusal fibre differentiation, these almost certainly involve larger, dense core vesicles. By contrast, turnover of the small clear vesicles is primarily modulated by mechanical stimuli applied to the terminal, making them concerned with information transfer in the opposite direction to that normally seen at a synapse.

The first strong evidence for a functional importance of vesicle recycling was the observation that stretch-evoked firing fails following tetanus toxin injection and at the same rate as neuromuscular synaptic transmission [52]. This shows the toxin's target, synaptobrevin, essential for docking and exocytosis of synaptic vesicles, is also crucial for maintaining spindle sensitivity to stretch.

These synaptic similarities and dissimilarities led us to term the organelles 'synaptic-like vesicles' or SLVs. As a further similarity, we found that spindle sensory terminals contain synaptic levels of the classical neurotransmitter glutamate, while others have shown they express vesicular glutamate transporters [82] (specifically vGluT1, although not vGluT2 or vGluT3), essential for loading vesicles with glutamate neurotransmitter.

Subsequently, we found SLVs are part of an activityregulated glutamate secretory system that is required to maintain normal spindle responses. Exogenous glutamate can double the stretch-evoked firing rate (Fig. 8a), while glutamate receptor antagonists can both inhibit this glutamate-mediated increase and, importantly, reduce firing if applied alone (Fig. 8b). Indeed, prolonged exposure ( $>4$ h) can entirely, and reversibly, abolish 


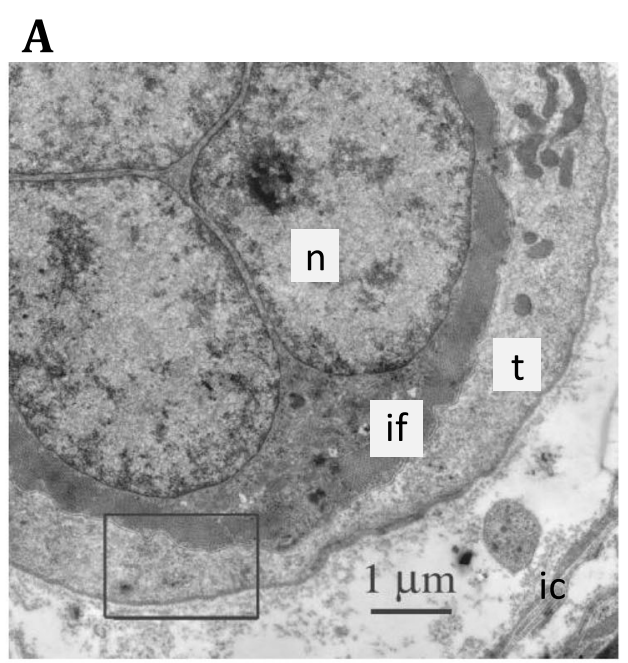

C

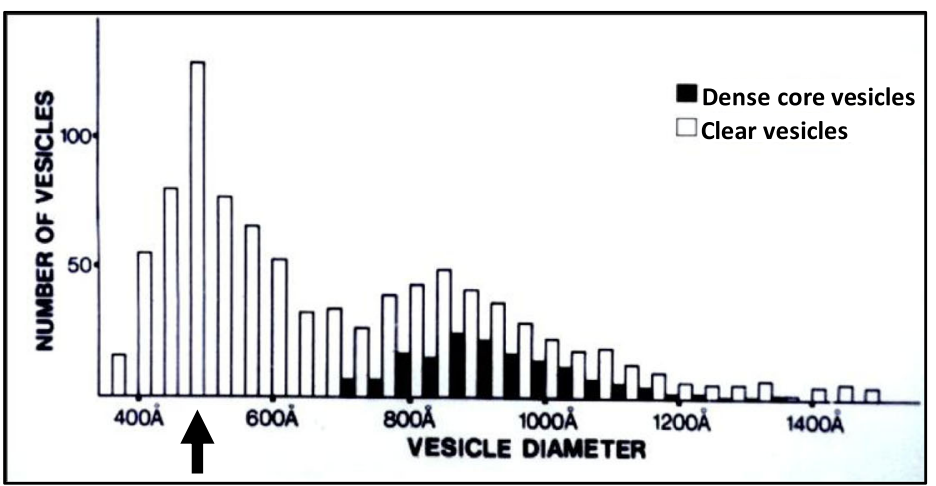

B

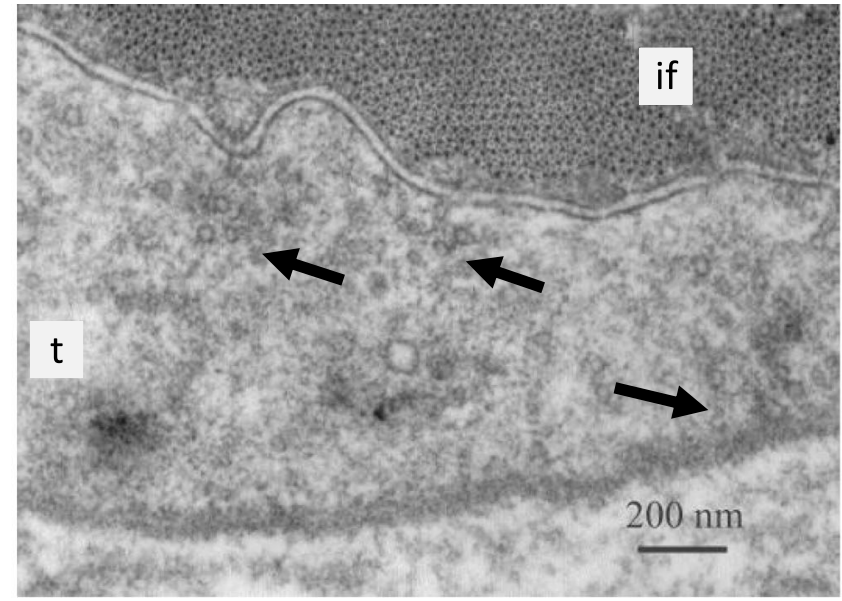

D

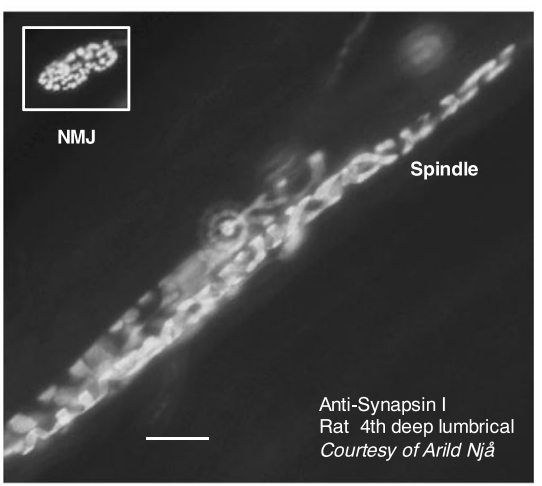

E

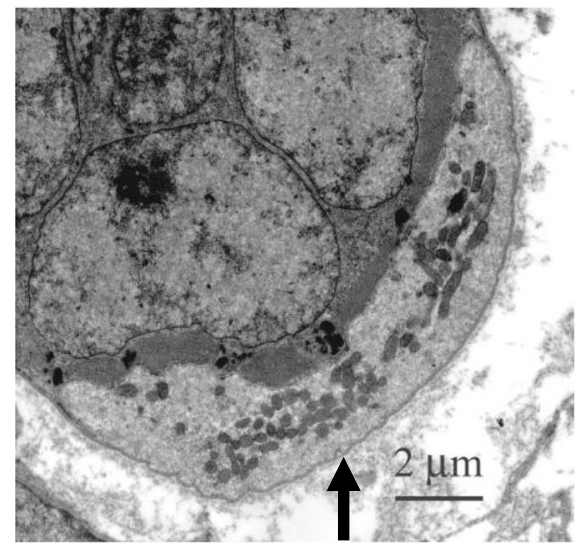

Fig. 6 Fifty-nanometre, clear synaptic-like vesicle ( $S L V$ ) clusters in spindle sensory terminals. a Electronmicrograph of a transverse section of the central portion of a nuclear bag intrafusal fibre (if) with its distinctive collection of prominent nuclei $(n)$ and an enclosing sensory terminal $(t)$. The boxed region is shown at higher magnification in (b), where distinctive clusters of synaptic-like vesicles can be seen (arrows), some aggregated towards and some away from, the muscle fibre. Quantification of vesicle diameters (c) shows the most abundant are clear and $50 \mathrm{~nm}(500 \AA)$ in size, similar to their synaptic counterparts. Synapsin I labelling (d), a presynaptic vesicle-clustering protein, is present in the typical annulospiral ending of a rat lumbrical primary sensory terminal. Labelling in a motor nerve terminal in the same muscle is of similar intensity (inset, for comparison; $N M J$, neuromuscular junction). Spindle terminals do not stain for synapsin II or III (Arild Njå, personal communication). Scale bar, $20 \mu \mathrm{m}$. e, f A coated pit of approximately 50-nm diameter in the axolemma of a sensory terminal, typical of endocytosis, as evidence of active SLV recycling. Note this pit is on the surface directed away from the nuclear bag fibre it encloses, although we have seen retrieval areas on both surfaces 
A

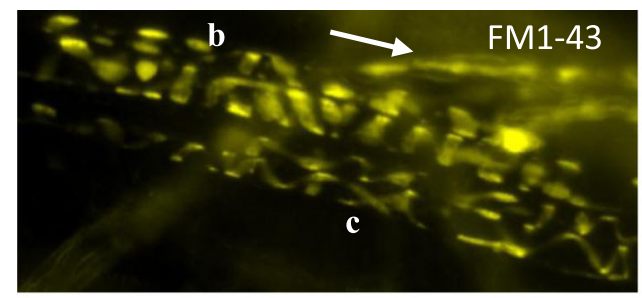

B

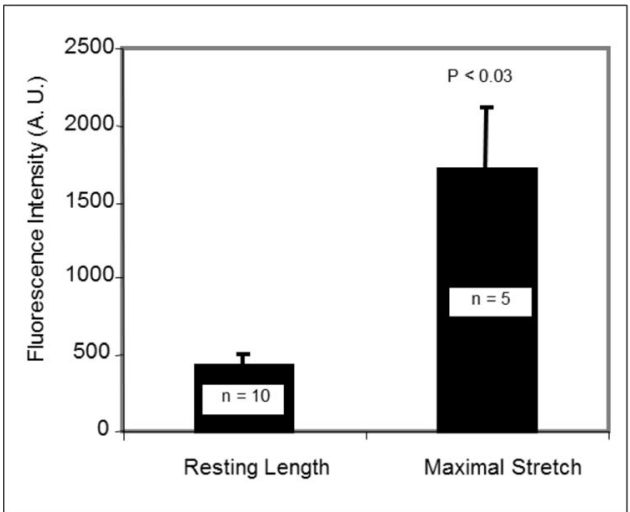

Fig. 7 FM1-43 labelling of differentiated primary spindle endings involves local synaptic-like vesicle recycling. Spontaneous FM1-43 labelling of primary endings in adult rat lumbrical muscle (a), showing characteristic differences in pitch, intrafusal fibre diameter and terminal ribbon width associated with nuclear bag $(b)$ and chain $(c)$ fibres. Incoming IA afferent axons also sequester dye (arrow) independent of activity due to their high myelin content. Intrafusal fibres enclosed by the endings are translucent, as they do not take up the dye. Terminal labelling is spontaneous but greatly increased by mechanical activity (repeated

stretch-evoked firing altogether. The latter observation and the blockade by tetanus toxin are strong evidence that glutamate release from SLVs is essential for maintaining spindle responsiveness, and over a prolonged timescale of hours, rather than directly involved in mechanotransduction itself. More recently, we have strengthened the evidence for endogenous glutamate secretion by showing that simply blocking membrane glutamate transporters with DL-threo- $\beta$-benzyloxyaspartic acid (TBOA; Fig. 8c) markedly increases stretch-evoked firing, presumably through extracellular accumulation of secreted glutamate. This endogenous secretion seems to involve SLVs, as responsiveness is inhibited by blocking exocytosis with $\mathrm{Ca}^{2+}$ channel inhibitors $\left(\mathrm{Co}^{2+}\right.$ and $\mathrm{Ni}^{2+} / \mathrm{Cd}^{2+}$, see earlier). Moreover, stimulating exocytosis to deplete SLVs with $\alpha$-latrotoxin [65] initially enhances, then inhibits firing (Fig. 8d). This action of $\alpha$-latrotoxin, the active ingredient of black widow spider venom, highlights another presynaptic similarity of spindle afferent terminals; they must express the latrotoxin receptor latrophilin and/or neurexin.

Another intriguing aspect of spindle glutamate sensitivity is the highly unusual pharmacology of the receptor involved. It is resistant to classical ionotropic (iGluR; kynurenate) or metabotropic (mGluR) receptor antagonists (MCPG (groups I and II) or CPPG and MAP4 (group III)), even applied together

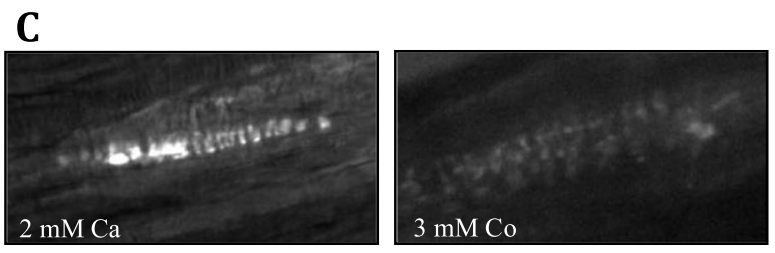

D

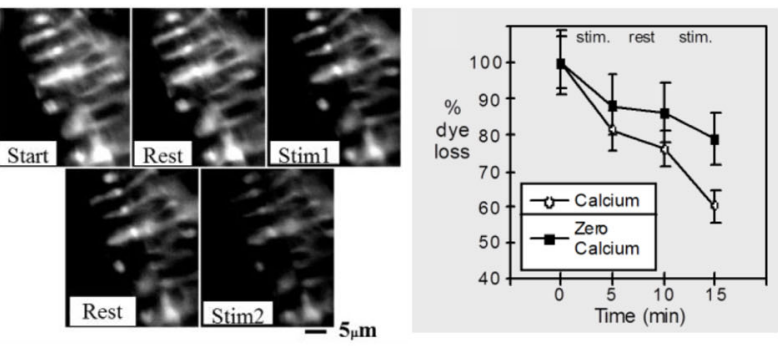

maximum stretch, b). It is also $\mathrm{Ca}^{2+}$ dependent, as it is essentially eliminated by the channel blocker $\mathrm{Co}^{2+}(\mathbf{c})$. d Unlike labelling by mechanosensory channel permeation, FM1-43 labelling in differentiated spindle terminals is reversible (d), showing clearly enhanced destaining with vibration (left images, $200 \mathrm{~Hz}, 50-\mu \mathrm{m}$ amplitude, $5 \mathrm{~min}$ ), a process which is also $\mathrm{Ca}^{2+}$ sensitive (right graph). This is consistent with FM1-43 uptake/release in differentiated terminals through local $\mathrm{Ca}^{2+}$-dependent recycling of SLVs in these endings ([16], b-d)

[16]. However, it is actually inhibited by the classical group I agonist R,S-DHPG, and particularly by PCCG-13 (Fig. 8b). PCCG-13 was developed by Pellicciari and colleagues [59] as a selective antagonist of a novel mGluR in the hippocampus, coupled to phospholipase D activation (PLD) [6,58]. We have confirmed the highly atypical and non-canonical pharmacology of the spindle mGluR in a recently completed extensive pharmacological investigation [76]. The mGluR-mediated increase in responsiveness in spindles is also linked to PLD, as the PLD inhibitor FIPI blocks both the response to exogenous glutamate and inhibits spindle firing when applied alone, in a dose-dependent manner. We have therefore termed this receptor the PLD-mGluR.

In summary, spindle responsiveness is both maintained and increased by a positive gain control system whereby SLVs release glutamate in a $\mathrm{Ca}^{2+}$ - and mechanical activitydependent manner, activating a PLD-mGluR receptor with a unique pharmacology (Fig. 9; Supplementary material S1). This system controls firing from an approximate doubling of firing rates at one extreme, to abolishing spindle output altogether at the other. Thus, this SLV-glutamate-PLD-mGluR system, operating over a minute-to-hour timescale, seems essential for ensuring spindle functionality in the long term. Given the 
A
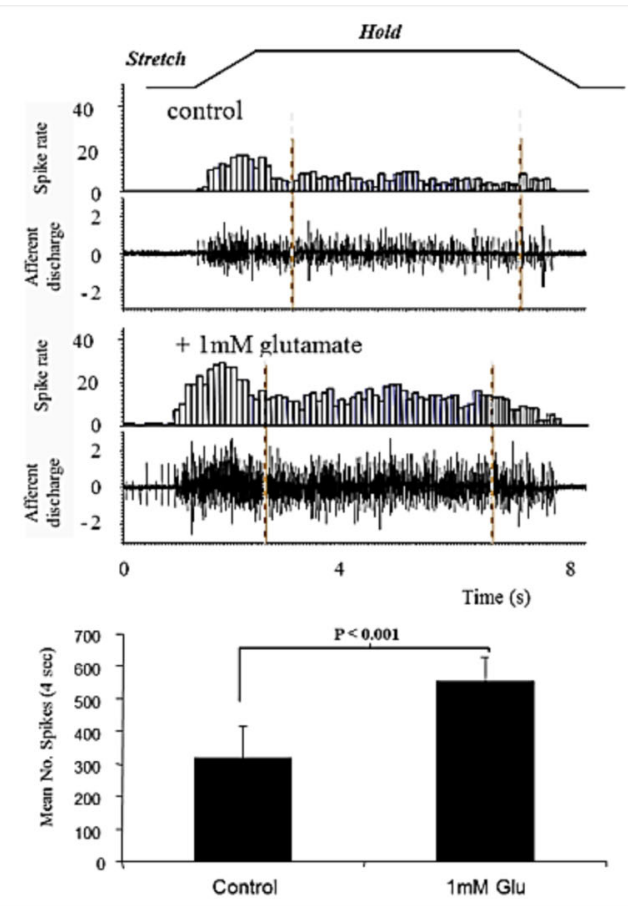

B
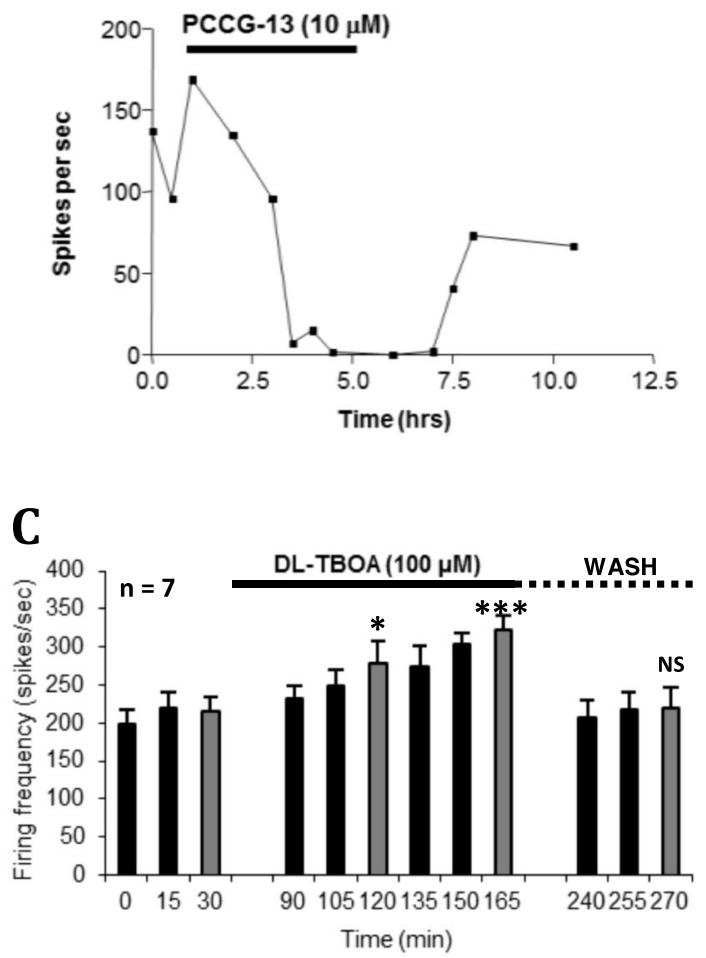

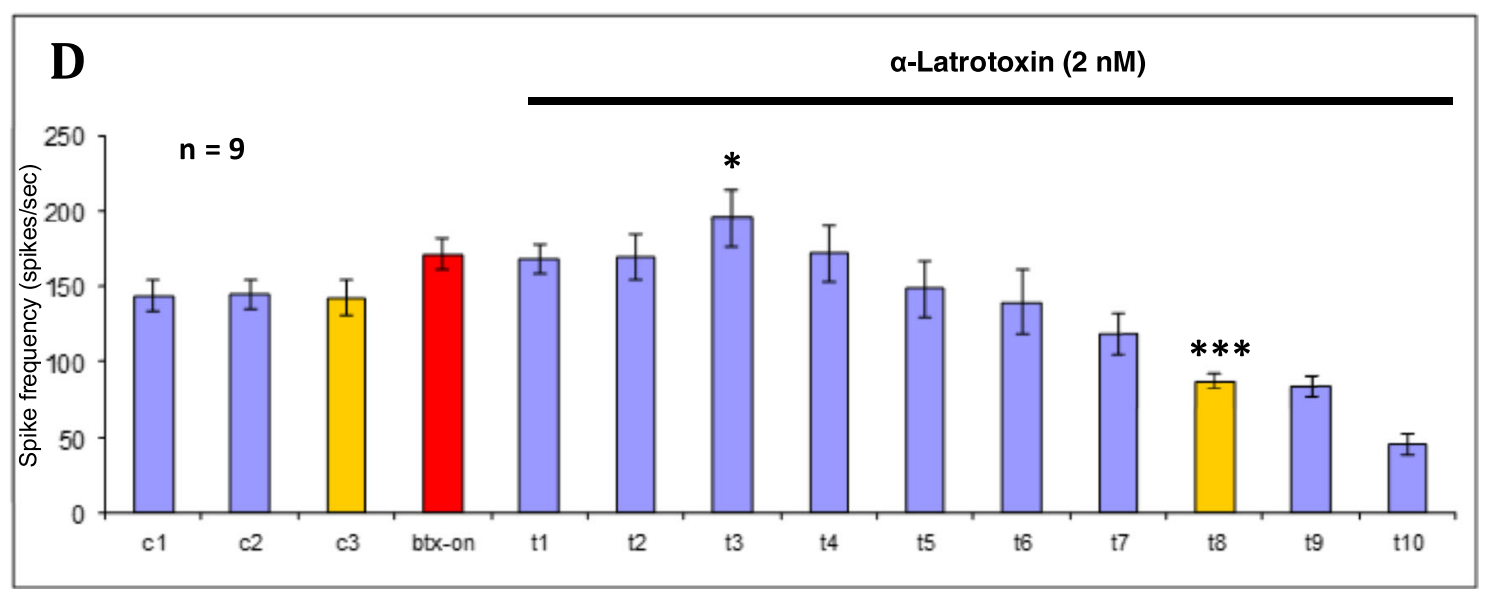

Fig. 8 Endogenous glutamate secretion from SLVs maintains spindle stretch-evoked responsiveness. a A standard trapezoidal stretch-and-hold ( $\sim 10 \%$ muscle length) applied to a rat lumbrical muscle containing 8-12 muscle spindles evokes robust spiking activity in the electroneurogram (afferent discharge) and quantified in the firing frequency histogram (spike rate). Exogenous glutamate $(1 \mathrm{~h}, 1 \mathrm{mM})$ can essentially double firing rate for the stretch. The histogram shows total firing within the 4-s plateau (hold phase) sample period indicated. Conversely, b inhibition of the highly atypical glutamate receptor with PCCG-13, applied in the absence of glutamate, can totally and reversibly block stretch-evoked spindle output. Note the timescale of hours, showing the long timecourse over which this modulation occurs. c Endogenous glutamate secretion occurs and is important for regulating firing, as blocking glutamate reuptake by terminal excitatory amino acid transporters (TBOA), again in

ubiquitous presence of SLVs in primary mechanosensory nerve terminals, and the very similar glutamate pharmacology we have found in the only two other mechanosensory systems we the absence of exogenous glutamate, enhances firing just as effectively as application of exogenous glutamate. ${ }^{*} P<0.05$; $* * * P<0.0001$ vs. 30 -min control firing (grey bars). 1- to 2-h wash reverses this effect (NS, not significantly different from pre-TBOA control). d Endogenous glutamate secretion is from SLVs. $\alpha$-Latrotoxin, which evokes uncontrolled vesicle release, and ultimately vesicle depletion from spindle and synaptic endings [64], initially enhances stretch-evoked firing $(* P<0.05)$ then inhibits firing $(* * * P<0.0001)$, as SLVs are first released, then depleted. $c 1-c 3$ are recorded every $15 \mathrm{~min}$, while $t 1-t 10$ are recorded at 30-min intervals. Btxon bungarotoxin was first applied for $30 \mathrm{~min}$ prior to $\alpha$-latrotoxin, to block spontaneous mechanical stimulation by fibre contraction driven by the $\alpha$-latrotoxin-stimulated ACh secretion from fusimotor and extrafusal synaptic motor nerve terminals ([16], a, b)

have examined - lanceolate terminals of the palisade endings of rodent hair follicles [10], and aortic baroreceptors [57] - this gain control system seems likely to be a common feature of all 

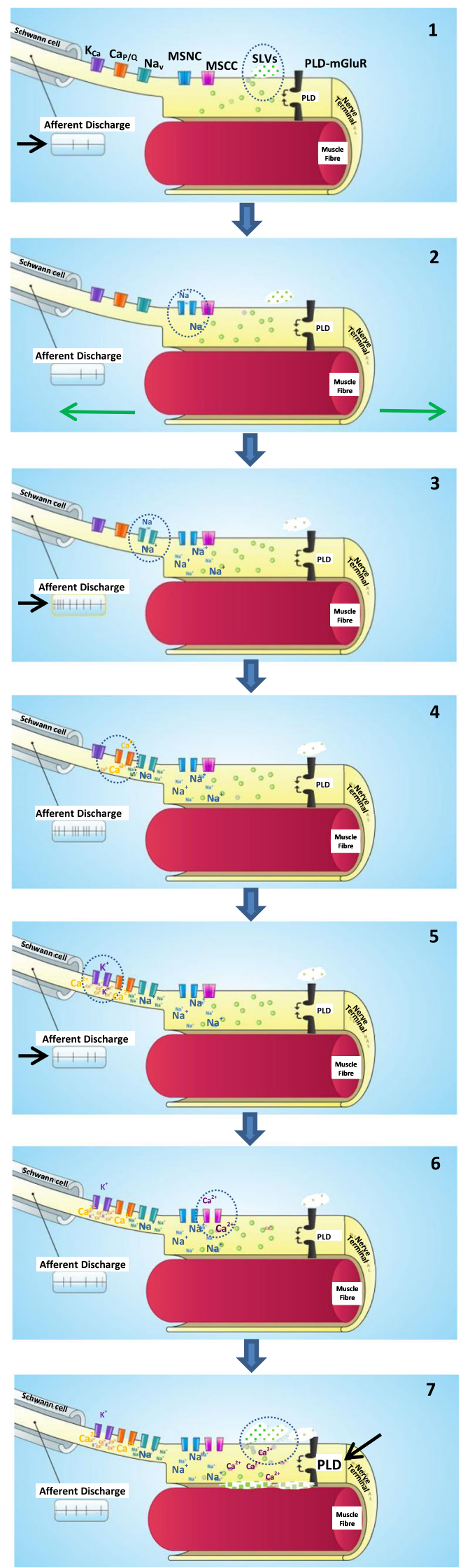

Fig. 9 Schematic summarising our current knowledge of the steps (1-7) from rest from mechanotransduction, through action potential encoding and firing rate determination, to autogenic sensitivity modulation. Areas of interest in each step are encircled or indicated by arrows.1, The myelinated primary afferent axon arrives from the left, produces a specialised encoding site at the unmyelinated heminode, then expands to form the sensory terminal proper, enclosing the intrafusal muscle fibre. The afferent discharge rate is shown in the panel bottom left (arrow). The terminal is the primary site of mechanotransduction through at least one type of mechanosensory channel $(M S)$ passing $\mathrm{Na}^{+}$and $\mathrm{Ca}^{2+}$. For convenience, these are shown separately (MSNC mechanosensitive $\mathrm{Na}^{+}$ channel, MSCC mechanosensitive $\mathrm{Ca}^{2+}$ channel). The terminal, as for all primary mechanosensory nerve endings, contains a population of $50-\mathrm{nm}$ diameter clear vesicles - synaptic-like vesicles (SLVS, green circles-see text for details). At rest, SLVs undergo spontaneous exocytosis of glutamate (green dots in dotted area) to activate the phospholipase D-coupled metabotropic glutamate receptor $(P L D-m G l u R)$, to enable and maintain ending ability to respond to stretch stimuli. Abbreviations: $C a_{P / Q} \mathrm{P} / \mathrm{Q}-$ type voltage-dependent $\mathrm{Ca}^{2+}$ channel, $K_{C a} \mathrm{Ca}^{2+}$-activated potassium channel, $N a_{v}$ voltage-dependent sodium channel. 2, Muscle stretch (green arrows) gates the MSNC, and $\mathrm{Na}^{+}$influx depolarises the terminal. 3, The depolarisation spreads electrotonically to the much narrower heminode encoding region, increasing action potential $(A P)$ firing (black arrow). Only the voltage-dependent $\mathrm{Na}^{+}$channel component of the AP is shown for simplicity. 4, The APs trigger the opening of $\mathrm{P} / \mathrm{Q}-$ type $\mathrm{Ca}^{2+}$ channels. 5 , The resulting $\mathrm{Ca}^{2+}$ influx opens $\mathrm{Ca}^{2+}$-activated $\mathrm{K}^{+}$channels $\left(K_{C a}\right)$, repolarising the heminode region. This negative feedback step moderates the firing rate (black arrow). 6, Simultaneously, the initial stretch also gates a mechanosensitive $\mathrm{Ca}^{2+}$ current (through the MSNC or another mechanosensory channel (MSCC)), allowing $\mathrm{Ca}^{2+}$ influx. 7, The increased intracellular $\mathrm{Ca}^{2+}$ enhances SLV exocytosis of glutamate, further activating the PLD-mGluRs. The resulting increase in PLD activity (black arrow) is part of a positive feedback loop (curved arrows) that maintains the ability of the ending to respond to subsequent stretches, perhaps by enhancing/maintaining MS channel insertion, through a mechanism that awaits identification. An animated version of this sequence is available online (see Supplementary material, S1)

such endings. The recent report of vGluTs in other lowthreshold mechanosensory terminals and accessory cells [81, 82] supports this view.

Of course, a positive feedback gain control, operating in isolation, would make spindle outputs very unstable, particularly during times of intensive activity. A negative feedback control must also be present to overcome this tendency (Fig. 10). This seems to involve a combination of $\mathrm{Ca}^{2+}$ and $\mathrm{K}[\mathrm{Ca}]$ channels $[47,55,79]$, some of which may contribute to the receptor potential itself [40] (Shenton et al., unpublished data), as described in a previous section. Normal activity would activate the voltage-gated $\mathrm{Ca}^{2+}$ channels, thereby opening the $\mathrm{K}^{+}$channels and reducing firing. Finally, these complex control systems seem likely to be confined to different loci as protein complexes and also tethered to cytoskeletal elements. We are now exploring one such binding protein, the PDZ-scaffold protein Whirlin. We have recently shown a mutation in Whirlin, which is responsible for the deaf/blindness of Usher's syndrome, selectively impairs stretch-evoked responsiveness in muscle spindles [23]. 


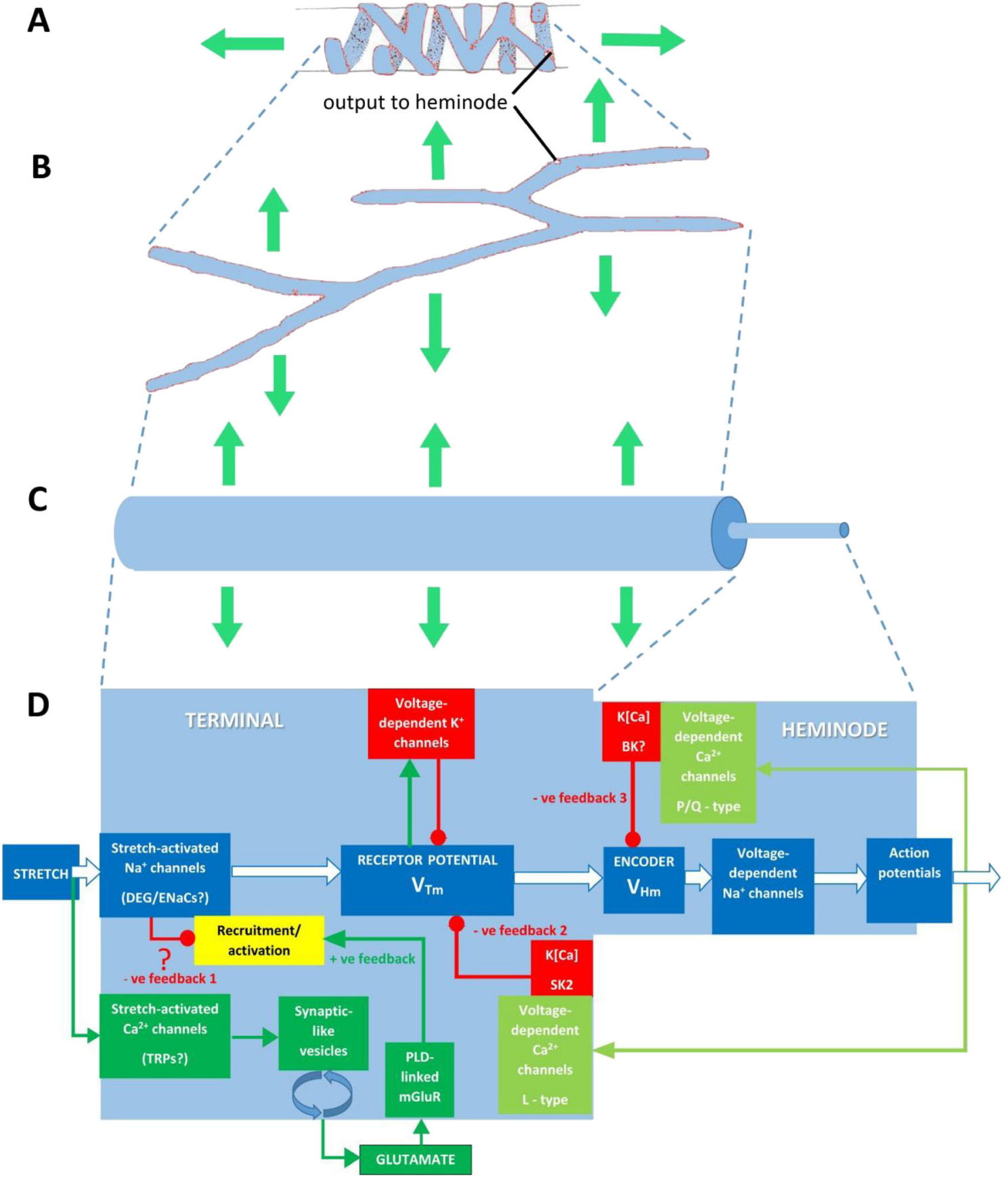

Fig. 10 a-d Progressive geometrical abstraction of a single terminal of a spindle primary ending, leading to a flow-chart summarising the events of mechanosensory transduction. Green block arrows in $(\mathbf{a}-\mathbf{c})$ indicate the direction and distribution of stretch applied to the terminal when the primary ending is lengthened during muscle stretch or fusimotor stimulation. a A single terminal in its annulospiral form, taken from a primary ending reconstructed from serial sections [8]. Several such terminals typically enclose a single intrafusal muscle fibre. The terminal is connected to its associated heminode by a short, unmyelinated preterminal axonal branch at the point shown. b The terminal unrolled and turned through $90^{\circ}$. Note that individual terminals may be repeatedly branched and that the direction of stress during stretch is orthogonal to the long axis of the terminal. c A terminal and its associated unmyelinated preterminal branch shown in abstract cylindrical form to indicate the relative diameters of these structures. The smaller preterminal branch to the right is about $1 \mu \mathrm{m}$ diameter. The lengths, especially that of the much larger terminal to the left, are highly variable. d Flow chart to illustrate the main events of mechanosensory transduction, as described in this review. The principal feed-forward pathway from stimulus (stretch) to output (action potentials) is shown by the white block arrows. We envisage that the overall gain of this pathway is controlled by several feedback pathways: negative feedback 1 is at present hypothetical and is included to account for the reversible silencing of the primary ending by PCCG-13 inhibition of the PLD-linked mGluR; the positive feedback pathway is the wellestablished SLV/glutamatergic loop; negative feedbacks 2 and 3 involve different kinds of $\mathrm{K}[\mathrm{Ca}]$, one located in the terminal, the other in the heminode and both perhaps triggered by action potentials opening voltage-gated Ca channels. Green lines and arrowheads indicate enhancing/ excitatory actions; red lines and circles indicate reducing/inhibitory actions 


\section{Conclusion}

Overall, it is clear that even in the absence of fusimotor activity, spindle stretch-evoked output is the product of complex and sophisticated regulatory gain controls, both positive and negative in nature. Coupled with the polyionic receptor currents and the potential for heteromeric transduction channels, the muscle spindle looks set to continue to keep its reputation as the most complex sensory organ after the special senses, at least for the foreseeable future.

Ethical standards The experiments performed by the authors all comply with UK Home Office legislation covered by the Animals (Scientific Procedures) Act, 1986, which was extant at the time of the experiments. To the best of our knowledge, other studies complied with the current laws of the country in which they were performed.

Conflict of interest The authors declare that they have no conflict of interest.

Open Access This article is distributed under the terms of the Creative Commons Attribution License which permits any use, distribution, and reproduction in any medium, provided the original author(s) and the source are credited.

\section{References}

1. Adrian ED, Zotterman Y (1926) The impulses produced by sensory nerve endings: part II. The response of a single end-organ. J Physiol 61:151-171, PMID: 16993780

2. Aguado F, Majó G, Ruiz-Montasell B, Llorens J, Marsal J, Blasi J (1999) Syntaxin 1A and 1B display distinct distribution patterns in the rat peripheral nervous system. Neuroscience 88:437-446, PMID: 10197765

3. Akoev GN, Alekseev NP, Krylov BV (1988) Mechanoreceptors: their functional organisation. Springer-Verlag, Berlin

4. Althaus M, Bogdan R, Clauss WG, Fronius M (2007) Mechanosensitivity of epithelial sodium channels $(\mathrm{ENaCs})$ : laminar shear stress increases ion channel open probability. FASEB J 21:23892399, PMID: 17426066

5. Árnadóttir J, O'Hagan R, Chen Y, Goodman MB, Chalfie M (2011) The DEG/ENaC protein MEC-10 regulates the transduction channel complex in Caenorhabditis elegans touch receptor neurons. J Neurosci 31:12695-12704. doi:10.1523/JNEUROSCI.4580-10. 2011, PMID: 21880930

6. Attucci S, Albani-Torregrossa S, Moroni F, Pellegrini-Giampietro DE (2001) Metabotropic glutamate receptors stimulate phospholipase $\mathrm{D}$ via different pathways in the adult and neonate rat hippocampus. Neurochem Res 26:1151-1155, PMID: 11700958

7. Awayda MS, Subramanyam M (1998) Regulation of the epithelial $\mathrm{Na}^{+}$channel by membrane tension. J Gen Physiol 112:97-111, PMID: 9689021

8. Banks RW (1986) Observations on the primary sensory ending of tenuissimus muscle spindles in the cat. Cell Tissue Res 246:309-319, PMID: 2946415
9. Banks RW (2005) The muscle spindle. In: Dyck PJ, Thomas PK (eds) Peripheral neuropathy, 4th edn. WB Saunders, Philadelphia, pp 131-150

10. Banks RW, Cahusac PMB, Graca A, Kain N, Shenton F, Singh P, Njå A, Simon A, Watson S, Slater CR, Bewick GS (2013) Glutamatergic modulation of synaptic-like vesicle recycling in mechanosensory lanceolate nerve terminals of mammalian hair follicles. J Physiol 591:2523-2540. doi:10.1113/jphysiol.2012.243659, PMID: 23440964

11. Banks RW, Hulliger M, Scheepstra KA, Otten E (1997) Pacemaker activity in a sensory ending with multiple encoding sites: the cat muscle-spindle primary ending. J Physiol 498:177-199, PMID: 9023777

12. Barker D (1974) The morphology of muscle receptors. In: Hunt CC (ed) Handbook of sensory physiology III/2 muscle receptors. Springer-Verlag, Berlin, pp 1-190

13. Behrendt H, Germann T, Gillen C, Hatt H, Jostock R (2004) Characterization of the mouse cold-menthol receptor TRPM8 and vanilloid receptor type-1 VR1 using a fluorometric imaging plate reader (FLIPR) assay. Br J Pharmacol 141:737-745, PMID: 14757700

14. Bendeich EG, Hooker WM, Karlsson UL (1978) Sensory nerve deformation in the stimulated frog muscle spindle. J Ultrastruct Res 62:137-146, PMID: 148517

15. Berkefeld H, Sailer CA, Bildl W, Rohde V, Thumfart J, Eble S, Klugbauer N, Reisinger E, Bischofberger J, Oliver D, Knaus H, Schulte U, Fakler B (2006) BK Ca-cav channel complexes mediate rapid and localized $\mathrm{Ca}^{2+}$-activated $\mathrm{K}^{+}$signaling. Science 314:615620, PMID: 17068255

16. Bewick GS, Reid B, Richardson C, Banks RW (2005) Autogenic modulation of mechanoreceptor excitability by glutamate release from synaptic-like vesicles: Evidence from the rat muscle spindle primary sensory ending. J Physiol 562:381-394, PMID: 15528245

17. Boyd IA (1976) The response of fast and slow nuclear bag fibres and nuclear chain fibres in isolated cat muscle spindles to fusimotor stimulation, and the effect of intrafusal contraction on the sensory endings. Q J Exp Physiol 61:203-254, PMID: 134389

18. Calabrese B, Tabarean IV, Juranka P, Morris CE (2002) Mechanosensitivity of N-type calcium channel currents. Biophys J 83:2560-2574, PMID: 12414690

19. Cauna N (1966) Fine structure of the receptor organs and its probable functional significance. In: De Reuck AVS, Knight J (eds) Touch, heat and pain. Churchill, London, pp 117-136

20. Coste B, Mathur J, Schmidt M, Earley TJ, Ranade S, Petrus MJ, Dubin AE, Patapoutian A (2010) Piezo1 and Piezo2 are essential components of distinct mechanically activated cation channels. Science 330:55-60. doi:10.1126/science.1193270, PMID: 20813920

21. De Camilli P, Vitadello M, Canevini MP, Zanoni R, Jahn R, Gorio A (1988) The synaptic vesicle proteins synapsin I and synaptophysin (protein P38) are concentrated both in efferent and afferent nerve endings of the skeletal muscle. J Neurosci 8:1625-1631, PMID: 3130468

22. Delmas P, Coste B (2013) Mechano-gated ion channels in sensory systems. Cell 155:278-284. doi:10.1016/j.cell.2013.09.026, PMID: 24120130

23. de Nooij J, Simon A, Doobar S, Steel KP, Jessell T, Banks RW, Bewick GS (2013) A role for whirlin in proprioceptor mechanotransduction. Proc 37th IUPS, PCA153

24. Drew LJ, Wood JN (2007) FM1-43 is a permeant blocker of mechanosensitive ion channels in sensory neurons and inhibits behavioural responses to mechanical stimuli. Mole Pain 3:1, PMID: 17207285

25. Duc C, Barakat-Walter I, Droz B (1993) Calbindin D-28 k- and substance P-immunoreactive primary sensory neurons: peripheral projections in chick hindlimbs. J Comp Neurol 334:151-158, PMID: 7691900 
26. Duc C, Barakat-Walter I, Droz B (1994) Innervation of putative rapidly adapting mechanoreceptors by calbindin- and calretininimmunoreactive primary sensory neurons in the rat. Eur J Neurosci 6:264-271, PMID: 8167847

27. Edgerton JR, Reinhart PH (2003) Distinct contributions of small and large conductance $\mathrm{Ca}^{2+}$-activated $\mathrm{K}^{+}$channels to rat Purkinje neuron function. J Physiol 548:53-69, PMID: 12576503

28. El-Tarhouni AB, Banks RW (1995) The distribution of calretinin in muscle receptors of the cat. J Physiol (Suppl) 487:P77

29. Fischer M, Schafer SS (2002) Effects of the calcium antagonist nifedipine on the afferent impulse activity of isolated cat muscle spindles. Brain Res 954:256-276, PMID: 15862530

30. Formigli L, Sassoli C, Squecco R, Bini F, Martinesi M, Chellini F, Luciani G, Sbrana F, Zecchi-Orlandini S, Francini F, Meacci E (2009) Regulation of transient receptor potential canonical channel 1 (TRPC1) by sphingosine 1-phosphate in $\mathrm{C} 2 \mathrm{C} 12$ myoblasts and its relevance for a role of mechanotransduction in skeletal muscle differentiation. J Cell Sci 122:1322-1333. doi:10.1242/jcs.035402, PMID: 19351713

31. Gale JE, Marcotti W, Kennedy HJ, Kros CJ, Richardson GP (2001) FM1-43 dye behaves as a permeant blocker of the hair-cell mechanotransducer channel. J Neurosci 21:7013-7025, PMID: 11549711

32. Garty H, Palmer LG (1997) Epithelial sodium channels: function, structure, and regulation. Physiol Rev 77:359-396, PMID: 9114818

33. Gees M, Colsoul B, Nilius B (2010) The role of transient receptor potential cation channels in $\mathrm{Ca}^{2+}$ signaling. Cold Spring Harb Perspect Biol 2:a003962. doi:10.1101/cshperspect.a003962, PMID: 20861159

34. Giraldez T, Dominguez J, Alvarez de la Rosa D (2013) ENaC in the brain-future perspectives and pharmacological implications. Curr Mol Pharmacol 6:44-49, PMID: 23547934

35. Gottlieb P, Folgering J, Maroto R, Raso A, Wood TG, Kurosky A, Bowman C, Bichet D, Patel A, Sachs F, Martinac B, Hamill OP, Honore E (2008) Revisiting TRPC1 and TRPC6 mechanosensitivity. Pflüg Arch 455:1097-1103, PMID: 17957383

36. Hager H, Kwon TH, Vinnikova AK, Masilamani S, Brooks HL, Frokiaer J, Knepper MA, Nielsen S (2001) Immunocytochemical and immunoelectron microscopic localization of alpha-, beta-, and gamma-ENaC in rat kidney. Am J Physiol Renal Physiol 280:F1093F1106, PMID: 11352848

37. Hietanen-Peltola M, Pelto-Huikko M, Rechardt L, Hokfelt T (1992) Calbindin D-28 k-immunoreactivity in rat muscle spindles during postnatal maturation and after denervation. Histochem J 24:673-678, PMID: 1429002

38. Holm AN, Rich A, Sarr MG, Farrugia G (2000) Whole cell current and membrane potential regulation by a human smooth muscle mechanosensitive calcium channel. Am J Gastrointest Liver Physiol 279:G1155-G1161, PMID: 11093937

39. Hulliger M, Banks RW (2009) A method for the study of the effects of combining multiple pseudorandom fusimotor stimulation on the responses of muscle-spindle primary-ending afferents. J Neurosci Methods 178:103-115, PMID: 19109995

40. Hunt CC, Wilkinson RS, Fukami Y (1978) Ionic basis of the receptor potential in primary endings of mammalian muscle spindles. J Gen Physiol 71:683-698, PMID: 149839

41. Hunt CC, Wilkinson RS (1980) An analysis of receptor potential and tension of isolated cat muscle spindles in response to sinusoidal stretch. J Physiol 302:241-262, PMID: 6447781

42. Iino S, Kobayashi S, Hidaka H (1998) Neurocalcin-immunopositive nerve terminals in the muscle spindle, Golgi tendon organ and motor endplate. Brain Res 808:294-299, PMID: 9767175

43. Iino S, Taguchi K, Maekawa S, Nojyo Y (2004) Motor, sensory and autonomic nerve terminals containing NAP-22 immunoreactivity in the rat muscle. Brain Res 1002:142-150, PMID: 14988044
44. Ismailov II, Berdiev BK, Shlyonsky VG, Benos DJ (1997) Mechanosensitivity of an epithelial $\mathrm{Na}^{+}$channel in planar lipid bilayers: release from $\mathrm{Ca}^{2+}$ block. Biophys J 72:1182-1192, PMID: 9138565

45. Jasti J, Furukawa H, Gonzales EB, Gouaux E (2007) Structure of acid-sensing ion channel 1 at $1.9 \AA$ resolution and low $\mathrm{pH}$. Nature 449:316-323, PMID: 17882215

46. Katz B (1966) Nerve, muscle, and synapse. McGraw Hill, London, p 193

47. Kruse MN, Poppele RE (1991) Components of the dynamic response of mammalian muscle spindles that originate in the sensory terminals. Exp Brain Res 86:359-366, PMID: 1721875

48. Lingueglia E (2007) Acid-sensing ion channels in sensory perception. J Biol Chem 282:17325-17329, PMID: 17430882

49. Ma HP, Li L, Zhou ZH, Eaton DC, Warnock DG (2002) ATP masks stretch activation of epithelial sodium channels in A6 distal nephron cells. Am J Physiol Renal Physiol 282:F501-F505, PMID: 11832432

50. Marrion NV, Tavalin SJ (1998) Selective activation of $\mathrm{Ca}^{2+}$-activated $\mathrm{K}^{+}$channels by co-localized $\mathrm{Ca}^{2+}$ channels in hippocampal neurons. Nature 395:900-905, PMID: 9804423

51. Matthews PB, Stein RB (1969) The sensitivity of muscle spindle afferents to small sinusoidal changes of length. J Physiol 200:723743, PMID: 4237132

52. Mizote M, Takano K (1985) The response of cat muscle spindle primary endings to FM muscle vibration during fusimotor stimulation or following local injection of tetanus toxin. In: Boyd IA, Gladden MH (eds) The muscle spindle. Macmillan Press, London, pp 365-369

53. Morgan DL, Prochazka A, Proske U (1984) The after-effects of stretch and fusimotor stimulation on the responses of primary endings of cat muscle spindles. J Physiol 356:465-477, PMID: 6240536

54. Nahirney PC, Ovalle WK (1993) Distribution of dystrophin and neurofilament protein in muscle spindles of normal and $\mathrm{Mdx}$ dystrophic mice: an immunocytochemical study. Anat Rec 235: 501-510, PMID: 8465985

55. Otten E, Hulliger M, Scheepstra KA (1995) A model study on the influence of a slowly activating potassium conductance on repetitive firing patterns of muscle spindle primary endings. J Theor Biol 173: 67-78, PMID: 7739213

56. Padinjat R, Andrews S (2004) TRP channels at a glance. J Cell Sci 117:5707-5709, PMID: 15537828

57. Paton JF, Banks RW, Bewick GS (2010) Modulation of afferent excitability and reflex responses by phospholipase D-coupled metabotropic glutamate receptors in the peripheral terminals of rat arterial baroreceptors. Proc Physiol Soc 19:C79

58. Pellegrini-Giampietro DE, Torregrossa SA, Moroni F (1996) Pharmacological characterization of metabotropic glutamate receptors coupled to phospholipase D in the rat hippocampus. Br J Pharmacol 118:1035-1043, PMID: 8799579

59. Pellicciari R, Marinozzi M, Costantino G, Natalini B, Moroni F, Pellegrini-Giampietro D (1999) (2R,1'S, 2'R,3'S)-2-(2'-carboxy-3'phenylcyclopropyl)glycine (PCCG-13), the first potent and selective competitive antagonist of phospholipase D-coupled metabotropic glutamate receptors: Asymmetric synthesis and preliminary biological properties. J Med Chem 42:2716-2720, PMID: 10411492

60. Piskorowski R, Haeberle H, Panditrao MV, Lumpkin EA (2008) Voltage-activated ion channels and $\mathrm{Ca}^{2+}$-induced $\mathrm{Ca}^{2+}$ release shape $\mathrm{Ca}^{2+}$ signaling in Merkel cells. Pflüg Arch 457:197-209. doi:10. 1007/s00424-008-0496-3, PMID: 18415122

61. Poppele RE (1973) Systems approach to the study of muscle spindles. In: Stein RB, Pearson KG, Smith RS, Redford JB (eds) Control of posture and locomotion. Plenum Press, New York

62. Poppele RE, Quick DC (1985) Effect of intrafusal muscle mechanics on mammalian muscle spindle sensitivity. J Neurosci 5:1881-1885, PMID: 3160835 
63. Price MP, Lewin GR, McIlwrath SL, Cheng C, Xie J, Heppenstall PA, Stucky CL, Mannsfeldt AG, Brennan TJ, Drummond HA, Qiao J, Benson CJ, Tarr DE, Hrstka RF, Yang B, Williamson RA, Welsh $\mathrm{MJ}$ (2000) The mammalian sodium channel $\mathrm{BNC1}$ is required for normal touch sensation. Nature 407:1007-1011, PMID: 11069180

64. Qi J, Peters KW, Liu C, Wang JM, Edinger RS, Johnson JP, Watkins SC, Frizzell RA (1999) Regulation of the amiloride-sensitive epithelial sodium channel by syntaxin 1A. J Biol Chem 274:30345-30348, PMID: 10521407

65. Queiroz LS, Duchen LW (1982) Effects of latrodectus spider venoms on sensory and motor nerve terminals of muscle spindles. Proc R Soc Lond B Biol Sci 216:103-110, PMID: 6137822

66. Quick DC, Kennedy WR, Poppele RE (1980) Anatomical evidence for multiple sources of action potentials in the afferent fibers of muscle spindles. Neurosciences 5:109-115, PMID: 6154269

67. Rossier BC (1998) Mechanosensitivity of the epithelial sodium channel (ENaC): Controversy or pseudocontroversy? J Gen Physiol 112: 95-96, PMID: 9689020

68. Satlin LM, Sheng S, Woda CB, Kleyman TR (2001) Epithelial $\mathrm{Na}^{+}$ channels are regulated by flow. Am J Physiol Renal Physiol 280: F1010-F1018, PMID: 11352841

69. Sharif-Naeini R, Folgering JH, Bichet D, Duprat F, Delmas P, Patel A, Honoré E (2010) Sensing pressure in the cardiovascular system: Gq-coupled mechanoreceptors and TRP channels. J Mol Cell Cardiol 48:83-89. doi:10.1016/j.yjmcc.2009.03.020, PMID: 19345226

70. Simon A, Banks RW, Bewick GS (2008) $\mathrm{K}_{\mathrm{Ca}}$ channels regulate stretch-evoked afferent firing from muscle spindles. Proc Physiol Soc 15:C45

71. Simon A, Shenton F, Hunter I, Banks RW, Bewick GS (2010) Amiloride-sensitive channels are a major contributor to mechanotransduction in mammalian muscle spindles. J Physiol 588:171-185. doi:10.1113/jphysiol.2009.182683, PMID: 19917568

72. Tadros SF, Kim Y, Phan PA, Birnbaumer L, Housley GD (2010) TRPC3 ion channel subunit immunolocalization in the cochlea. Histochem Cell Biol 133:137-147. doi:10.1007/s00418-009-0653-6, PMID: 19882163
73. Trebak M (2010) The puzzling role of TRPC3 channels in motor coordination. Pflüg Arch 459:369-375. doi:10.1007/s00424-0090740-5, PMID: 19823866

74. Venkatachalam K, Montell C (2007) TRP channels. Annu Rev Biochem 76:387-417, PMID: 17579562

75. Watson S, Aryiku C, Banks RW, Bewick GS (2010) Comparison of gadolinium and FM1-43 as blockers of stretch-evoked firing of rat muscle spindle afferents. Proc Physiol Soc 21:PC22

76. Watson S, Zanato C, Dall'Angelo S, Banks RW, Greig I, Zanda M, Bewick GS (2012) Pharmacological profile of non-canonical mGluR regulating mechanosensory nerve terminal firing. Proc Physiol Soc 27:PC46

77. Wei ET, Seid DA (1983) AG-3-5: a chemical producing sensations of cold. J Pharm Pharmacol 35:110-112, PMID: 6131976

78. Werle MJ, Roder J, Jeromin A (2000) Expression of frequenin at the frog (Rana) neuromuscular junction, muscle spindle and nerve. Neurosci Lett 284:33-36, PMID: 10771155

79. Westbury DR (1985) Evidence for the involvement of calcium activated potassium conductance in frog muscle spindle sensory endings. In: Boyd IA, Gladden MH (eds) The muscle spindle. Macmillan Press Ltd, London, pp 359-363

80. Womack MD, Chevez C, Khodakhah K (2004) Calcium-activated potassium channels are selectively coupled to $\mathrm{P} / \mathrm{Q}$-type calcium channels in cerebellar Purkinje neurons. J Neurosci 24:8818-8822, PMID: 15470147

81. Woo SH, Baba Y, Franco AM, Lumpkin EA, Owens DM (2012) Excitatory glutamate is essential for development and maintenance of the piloneural mechanoreceptor. Development 139:740-748. doi:10. 1242/dev.070847, PMID: 22241839

82. Wu SX, Koshimizu Y, Feng YP, Okamoto K, Fujiyama F, Hioki H, Li YQ, Kaneko T, Mizuno N (2004) Vesicular glutamate transporter immunoreactivity in the central and peripheral endings of muscle-spindle afferents. Brain Res 1011:247-251, PMID: 15157812

83. Zelená J (1994) Nerves and mechanoreceptors. Chapman, Hall, London 